J OURNAL OF French and Francophone Philosophy
REV VE DE L A

philosophie française et de langue française

\title{
Genetic Enhancement and the Biopolitical Horizon of Class Conflict
}

Wade Roberts

Journal of French and Francophone Philosophy - Revue de la philosophie française et de langue française, Vol XVIII, No 1 (2008-2010) pp. 27-42.

\author{
Vol XVIII, No 1 (2008-2010) \\ ISSN 1936-6280 (print) \\ ISSN 2155-1162 (online) \\ DOI $10.5195 /$ jffp. 2010.170 \\ http://www.jffp.org
}

\section{(c) EY-NC-ND}

This work is licensed under a Creative Commons Attribution-Noncommercial-No Derivative Works 3.0 United States License.
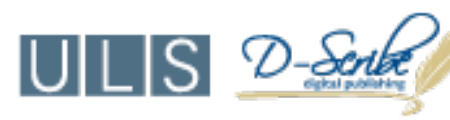

This journal is operated by the University Library System of the University of Pittsburgh as part of its D-Scribe Digital Publishing Program, and is co-sponsored by the University of Pittsburgh Press 


\title{
Genetic Enhancement and the Biopolitical Horizon of Class Conflict
}

\author{
Wade Roberts \\ Juniata College
}

\section{Introduction}

As Diane Paul has noted, the term 'eugenics' (which was initially coined by the British scientist Francis Galton in 1883) draws on the Greek word eugenes ("good in birth"). ${ }^{1}$ The Greek patrimony of the term is appropriate, given that one of the most (in)famous eugenics programs in the history of Western thought is outlined in Book Five of Plato's Republic, where Socrates proposes that the philosopher-kings arrange, through an elaborate scheme which relies heavily on deception and intrigue, for selected partners to mate with one another in order to produce individuals who are fit to govern in Kallipolis. ${ }^{2}$ Galton himself characterized eugenics as "the science of improving stock" which would deal with the question of how to facilitate "judicious mating" (Galton's phrase), and it proposed to "[take] cognizance of all influences that tend in however remote degree to give the more suitable races or strains of blood a better chance of prevailing speedily over the less suitable than they otherwise would have." ${ }^{3}$

The sordid history of eugenics, and more specifically of its political uses and abuses, during the twentieth century is too well known to necessitate a recapitulation in the present essay. ${ }^{4}$ Suffice it to say that eugenics movements had a decidedly authoritarian — and even genocidal—bent, as evidenced most clearly by Nazi attempts to 'regenerate' an Aryan race which had supposedly fallen into decline through a program of, on the one hand, exterminating hereditary 'undesirables', while at the same time offering reproductive incentives to 'pure-blooded' Germans. ${ }^{5}$

After the Second World War, the eugenics movement fell into disrepute (for obvious reasons). In recent years, however, there has been a renewed interest in the possibility of using genetic engineering to (again using 
Galton's phrase) "improve human stock". Defenders of genetic engineering have argued that we could modify an individual's genetic composition in order to eliminate crippling diseases such as Tay-Sachs, while its most ardent defenders have endorsed the even stronger position that we could use technologies of genetic enhancement in order to improve an individual's capacity for achievement within targeted areas (such as memory, intelligence, etc.). Indeed, the advocates of genetic enhancement have promoted the return of eugenics in a new, market-oriented context (often referred to as "liberal eugenics") that would operationalize the right of parents to select hereditary traits for their children which they regarded as desirable; in short, it would replace the discredited authoritarian paradigm with a neoliberal approach to genetic selection, allowing parents to create socalled 'designer babies' which conform to their consumer preferences.

While commentators across the political spectrum (from Habermas on the left to Fukuyama on the right), however, have offered criticisms of the at times euphoric celebration of the emancipatory possibilities afforded to humanity by genetic engineering, ${ }^{6}$ one potential concern has largely fallen by the wayside. Numerous authors have discussed the threats posed to democracy by the use of genetic engineering (i.e. given that the wealthy could presumably access the new technology more readily than the poor, its use threatens to exacerbate already significant inequalities), but only Lee Silver and Francis Fukuyama (at least to my knowledge) have examined the possibility that we might confront the expansion of what I'll call, following Michel Foucault and Enzo Traverso, "class racism" (which for the purposes of the present essay I simply understand as discriminatory attitudes or practices that are grounded in the biologization of socioeconomic differences). ${ }^{7}$ In the following essay I would like to explore this question in greater detail. I will argue that liberal eugenics, which is supposed to promote individual freedom by giving parents the right to select hereditary dispositions for their children, in actuality threatens to undermine, in important ways, the foundations of an egalitarian liberal order by promoting the growth of class racism. The essay is divided into four parts. In the next section (II), I will describe liberal eugenics in greater detail. In section three, I will provide a brief overview of Foucault's discussion of class racism, in order to provide the context for section four, in which I examine how class racism might emerge from the expanded use of genetic engineering. I will examine the dystopian implications of such a scenario, and in section five I will conclude with a series of reflections on how, precisely, opponents of liberal eugenics should think about it at the political level, and what, if anything, they can do to oppose it. It's important to add one final note before proceeding to the main discussion: from a moral standpoint, there are compelling reasons to oppose genetic engineering for purposes of human enhancement, which I'm unable to present here in any detail. Suffice it to say that there are immense risks associated with germline engineering, 
and there are serious questions about the threats it poses to a future agent's autonomy. In the present essay, however, I'm more interested in the political dynamics of genetic enhancement, with a particular focus on the question of how its use could lead to the expansion of class racism and, given that risk, how we should think about it in political terms.

\section{What is Liberal Eugenics?}

In an article which initially appeared in 1998, Nicholas Agar introduced the idea of "liberal eugenics". 8 He eventually expanded the article into a book, defining the term with greater specificity. ${ }^{9}$ In both the original essay, as well as the more fully developed account contained in his book-length study, Agar contrasts liberal eugenics with its authoritarian predecessors. The proponents of authoritarian eugenics proposed to use the state (and all of its coercive power) in order to carry out eugenic policies, with the ultimate goal of building a new social order which corresponded to a particular conception of the good. In the case of Plato, for example, eugenics is a means to producing individuals who are capable of ruling Socrates' ideal regime in the most judicious fashion. There is a clear conception of how the good society is ordered, and Socrates contends that eugenics is a powerful instrument for bringing such a society into existence.

The defenders of liberal eugenics, on the other hand, emphasize the fact of pluralism in modern liberal societies, and insist that the state shouldn't use its power in order to enforce eugenic policies; "[r]ather, it [liberal eugenics] would foster the development of a wide range of technologies of enhancement [and] parents' particular conceptions of the good life would guide them in their selection of enhancements for their children." ${ }^{10}$ In other words, liberal eugenics recognizes that in contemporary industrial/postindustrial societies which are characterized by high degrees of religious and cultural diversity, ${ }^{11}$ it's problematic for the state to endorse a particular conception of the good, and it's even more problematic to believe that the state is justified in using coercive forms of genetic engineering in order to promote a specific vision of the good life. Liberal eugenics begins, then, from the premise that pluralism concerning the idea of the good is an inexorable feature of modern societies, and defends the (presumptive) right of parents to make genetic choices with minimal state interference based on their particular conception(s) of the good (although Agar stipulates that there are qualified limits; he believes, for example, that parents should not opt for genetic modifications which would substantially compromise the child's future ability to make autonomous decisions when $\mathrm{s} /$ he reaches maturity ${ }^{12}$ ).

On Agar's description, therefore, liberal eugenics isn't susceptible to the standard criticisms which are raised against using genetic engineering to 
improve human beings (i.e. the dangers of state-sponsored eugenics, threats to individual liberty, etc.); indeed, to the extent that it proposes the enshrinement, and even expansion, of parents' reproductive freedoms, it represents a marked departure from the coercive version of eugenics that is most closely associated with the authoritarian projects of the late nineteenth and early twentieth centuries, in which particular groups were discouraged, or even forbidden, by the state to reproduce. ${ }^{13}$ If anything, liberal eugenics would open up a space for reproductive choice in which parents are provided with a wider assortment of options; genetic engineering would open up new vistas of reproductive liberty for couples.

Thus, Agar is able to establish a clear, and morally significant, difference between liberal eugenics and its authoritarian predecessors. But he does so at a high justificatory price, given that the appeal to expanded reproductive freedoms generates a host of new questions and moral dilemmas. As mentioned above, for example, one of the most perplexing issues that arises from an appeal to the importance of safeguarding the reproductive freedom of parents is that it risks violating the rights of a future person. Assume, for example, that a set of parents would like their child to become a basketball superstar, and they engineer for height. If the child decides that $\mathrm{s} /$ he would like to become a world-class horse jockey, $\mathrm{s} /$ he has been placed at a significant disadvantage. This is precisely why Agar establishes limits on the parents' reproductive liberty; it threatens to undermine the autonomy of another moral agent.

Yet if there are moral dilemmas that arise from Agar's attempt to rehabilitate the image of eugenics by appealing to our moral intuitions concerning the value of reproductive freedom, there are also significant political questions which emerge from his analysis (although at the limit, it's not easy to separate out moral from political concerns, especially in the case of questions surrounding the defensibility of genetic engineering). On the assumption that technologies of genetic engineering would initially prove costly, one of the most prominent concerns which features in the secondary literature is the issue of whether, or to what extent, the widespread use of genetic engineering by the wealthy could exacerbate already existing inequalities between the rich and poor. Indeed, in celebrating the expansion of consumer freedoms which neoliberals regard as one of the virtues of market-oriented genetic engineering, there is a tendency to minimize the challenges which genetic enhancement poses from the standpoint of social justice.

While the political dangers of heightened inequality are fairly obvious, however, there is one potential threat which most commentators have ignored altogether. If we concede that the wealthy would have a monopoly on technologies of genetic enhancement (at least from the standpoint of access)—a point which seems difficult to contest, given our market-oriented 
approach to administering health-care ${ }^{14}$-then not only would we have to deal with the implications of the widening social gap for liberal democracies (which would include, obviously, an exacerbation of the already significant deficit which the poor confront in terms of their ability to influence political processes, as well as increased cynicism about the supposedly meritocratic distribution of positions in the social order), but we could also confront the spread of what I'll call class racism. In the next section, therefore, I will give an account of Foucault's discussion of class racism in Society Must Be Defended, which will provide an overview of class racism's past before we turn to an examination of its (potential) future.

\section{A Genealogy of Class Racism}

As mentioned in the introduction, I define class racism as discriminatory attitudes or practices which are grounded in the biologization of socioeconomic differences. ${ }^{15}$ In this section I'd like to provide a brief overview of the historical emergence and deployment of class racism through a reconstruction of Foucault's Society Must Be Defended, which offers a genealogical examination of how the discourse of race war was taken up in different historical contexts by competing classes (who in turn deployed the language of race in order to mobilize support against their enemies).

Foucault claims that, beginning in the Middle Ages, coercive power was monopolized by the State. As a result, "private conflicts" started to disappear; relations of force developed at the frontiers of the State with other nations, but the social body itself was pacified and judicial order replaced the chaos of warfare. ${ }^{16}$ Eventually, in early modernity, a professionalized military apparatus emerged, and the army was transformed into a governmental institution. As war was expelled from the private sphere, however, or centralized under State control, a new historico-political discourse emerged which regarded war as "the ineradicable basis of all relations and institutions of power" ${ }^{\prime 17}$ and was explicitly opposed to "philosophico-juridical" rationalities ${ }^{18}$. Its origins date to the period immediately after the religious and civil conflicts of sixteenth century Europe (although it re-emerged in later epochs) ${ }^{19}$, and Foucault characterizes the discourse as a polemical attack on the rhetoric and institutions of sovereignty. Rather than glorifying monarchy it posited that the king had used war, cruelty and bloodshed in order to subjugate his enemies, and it focused on the conflict which continued to rage beneath the veneer of pacification and legal order.

Foucault argues that the new discourse was highly mobile, and it was taken up by both aristocrats and populists; the common point of attack, however, was royal power. ${ }^{20}$ It emerged in the seventeenth century, and it 
had, in effect, two births. First, it arose in the 1630's during the postrevolutionary period of English history, where it was associated with the populist/petit-bourgeois discourse of the Puritans and Levellers. We encounter its birth a second time at the end of Louis XIV's reign (approximaely fifty years later) in the context of Boulainviller's aristocratic critique of monarchical excess. ${ }^{21}$ Even at the earliest stages of its formation, however, the new discourse was organized around principles of race war; beneath the appearance of order and unity, differences of ethnicity, language and civilization divided the social body into warring camps. As Foucault writes, "it forms the matrix for all the forms beneath which we can find the face and mechanism of social warfare."22

Eventually, the discourse of race war underwent two important transcriptions. First, there was a biologistic transcription which drew on the concepts and vocabulary of what Foucault calls a "materialist anatomophysiology"; it appeared both in hyper-nationalistic movements, as well as in nationalistic struggles against the State apparatus, eventually surfacing in justifications of colonialism. A second transcription, which occurred in the early part of the nineteenth century, appropriated the discourse of race war but transformed it into the language of class struggle. ${ }^{23}$ The biological transcription eventually metastasized into a full-blown racism, with the idea that the polarity was now understood as a binary division within the race itself; in short, we see the emergence of a superrace and a subrace, where the struggle is increasingly played out between the dominant race and its degenerate other, an other which was initially subjugated but has now reemerged to torture the master race and destroy it. ${ }^{24}$

As the new racialist discourse gradually seized power, however, it turned the force of the state against the "subrace"; it established a biological norm, the norm of the true race, against which the degenerate enemy was measured, with the correlative emergence of practices and institutions designed to safeguard the body of society through exclusion and segregation. In other words, the new racialist discourse abandoned the idea that society was divided between warring factions, exchanging it for the notion that the true race had to defend society against threats to its biological integrity. ${ }^{25}$ As Foucault writes, "[a]t this point, the racist thematic is no longer a moment of struggle against between one social group and another; it will promote the global strategy of social conservatives." 26 Thus, "we see the appearance of a State racism: a racism that society will direct against itself, against its own elements and its own products."27

It is here, against the backdrop of an emergent State racism, that we encounter the more specific formation of class racism. Balibar has noted that Disraeli viewed the state as split into "two nations", and argues that Disraeli's perspective was typical of the bourgeoisie's response to progressive social movements. It was necessary to split off the property- 
owning classes from industrial workers, who were in turn regarded as a quasi-biological menace to the social order. ${ }^{28}$ Traverso, following Sartre, notes that French literature in the period following the defeat of the Commune began to racialize, and call for the segregation of, the workingclass. $^{29}$ In the second half of the nineteenth century, crowd psychologists such as Le Bon compared the urban proletariat to the so-called "inferior races", 30 a theme which was eventually taken up in the eugenicist work of Vacher de Lapouge, who contended that social inequalities were grounded in heredity. ${ }^{31}$ During roughly the same period (i.e. the last third of the nineteenth century) we encounter what Foucault calls "the urban reshaping of Paris" carried out by Haussmann, in which the city was effectively divided into rich and poor areas. As Foucault writes, "[ $t]$ he feeling was that cohabitation between rich and poor in an undifferentiated environment constituted a health and political hazard for the city." 32 Foucault himself has shown how the eugenics movement of the nineteenth century contributed to the birth of Nazism in the twentieth, ${ }^{33}$ while Traverso speculates that there was a link between class racism and biologized anti-Semitism. ${ }^{34}$ Likewise, authors such as Edwin Black ${ }^{35}$ and Ladelle McWhorter ${ }^{36}$ have documented the prevalence of class racism in the American eugenics movements of the late nineteenth/twentieth centuries.

\section{Liberal Eugenics and the Future of Class Racism}

At first glance, it seems implausible to believe that liberal eugenics, which defends the rights of parents to enhance their children and emphasizes the importance of defending their autonomy against state coercion, could have any relationship, however, tangential, to the historical discourses of class racism discussed in section three of this essay. While it is true, however, that the normative framework used to justify liberal eugenics has no obvious connection to ideologies of race war, it is nevertheless the case that the practice of genetic engineering could have the unintended consequence of establishing the parameters for a class warfare which is increasingly defined in racialized terms. Indeed, Lee Silver envisions a dystopian future in which society is divided into distinct sub-races; the 'Naturals' have elected to forgo use of genetic enhancement, either for moral reasons or, more generally, because they lack financial resources, ${ }^{37}$ while the members of the second class, referred to as the 'Gene-Enriched' (or, the 'GenRich', an elite group which comprises roughly ten percent of the American population), carry synthetic genes which have allowed them to excel in sports, science, politics and business. ${ }^{38}$ They constitute what Silver describes as a "modern-day hereditary class of genetic aristocrats." ${ }^{39}$ Over time, the genetic advantages which members of GenRich enjoy vis-à-vis their unenhanced fellow citizens have grown so significant that they exercise a thoroughgoing control of the major institutions in society; their intellectual 
capacities surpass that of so-called Naturals to such an extent that the latter are simply incapable of challenging the hegemony of their genetic "superiors".

How, exactly, would such as scenario play out in a political context? There are obviously a number of possibilities, but in Our Posthuman Future, Francis Fukuyama has speculated that it could lead to the explosion of class racism and the subversion of foundational egalitarian assumptions which are essential to the (relative) stability of liberal democracies. ${ }^{40}$ Indeed, at the limit he claims that "[i]f wealthy parents suddenly have open to them the opportunity to increase the intelligence of their children as well as that of all their subsequent descendents, then we have the makings not just of a moral dilemma but of a full-scale class war." 41 He imagines a society divided along class lines, but it is a form of class division with a perversely biopolitical twist in which "[y]ou can increasingly tell the social background of a young person by his or her looks and intelligence; if someone doesn't live up to social expectations, he blames bad genetic choices by his parents rather than himself." ${ }^{42}$ Thus, while it's certainly true that contemporary societies are already characterized by high levels of class stratification, with all of the attendant problems which ordinarily accompany sharp demarcations in social status, and while it's furthermore the case that individuals are often subject to prejudicial judgment/treatment, stereoytping, etc. based on their appearance or intellect, under Fukuyama's scenario such judgments would increasingly reflect the belief that class differences are the result of biological factors, and individuals who were either unable or unwilling to use the new technologies of genetic modification would constitute a new "subrace" of hereditary inferiors.

Indeed, both Fukuyama and Michael Sandel have pointed out that, in our present society, we tend to believe that at least part of our success is the result of accident and luck. ${ }^{43}$ This leads, in turn, to a recognition of the contingency of our circumstances, which (hopefully) creates a sense of solidarity with others. As Sandel writes, "the more alive we are to the chanced nature of our lot, the more reason we have to share our fate with others." ${ }^{44}$ But if the engineered elites begin to feel that their achievements are the result of their parent's genetic choices, they may begin to believe that they deserve whatever rewards they enjoy. Fukuyama speculates that "[t]hey may, in short, feel themselves to be aristocrats, and unlike aristocrats of old, their claim to better birth will be rooted in nature and not convention." ${ }^{45}$

Here it's important to add a clarifying remark in order to ward off one possible objection to the scenario outlined above. In the absence of further argumentation, one could possibly infer that Fukuyama believes that it's sufficient for the wealthy to enhance their children in order to produce the kinds of changes which would give their offspring a genetic advantage. In 
other words, one could infer that he presupposes the correctness of genetic determinism, which is the assumption that there is a (more or less) straightforward connection between a person's genotype and the observable traits/character which a person develops (which are often referred to, in more technical terminology, as an individual's phenotype). But the phenotypical expressions of a person's genetic composition are the result of complex interactions between genes and the environment; thus, it's problematic to believe that simply because parents can engineer for, say, intelligence, it will follow with necessity that the child will develop superior intellectual abilities. We don't, however, need to endorse the fallacious assumptions of genetic determinists in order to show why Fukuyama is justified in worrying about the potential biologization of class differences. If we add the reasonable assumption that the majority of wealthy parents are also able to provide their children with better education, nutrition, etc., in addition to giving them a genetic head-start, we can easily deflect the determinist objection. ${ }^{46}$

In addition to the concerns mentioned above, another worry is that members of the new subclass would be labeled "genetically at risk". 47 As Nikolas Rose has noted, bioethicists are concerned that individuals who are labeled "genetically at risk" would have to navigate a complex set of discriminatory practices. The most familiar concerns have to do with the denial of health insurance, or even employment, based on genetic information. ${ }^{48}$ A second, and less familiar, potential difficulty, however, is the use of genetic testing in educational contexts. Rose highlights the existence of pilot programs which screen students for genetic abnormalities (such as duplicate $\mathrm{X}$ or $\mathrm{Y}$ chromosomes) with the goal of providing medical interventions. ${ }^{49}$ In addition, he emphasizes the concerns of authors such as Dorothy Nelkin and Laurence Tancredi that genetic screening could become a standard form of testing in schools, which would lead to discrimination against students with genetic irregularities and "a life sentence under the gaze of the therapeutic professionals." 50

\section{Opposing Liberal Eugenics}

Defenders of enhancement have responded in a variety of ways to the scenarios of heightened inequality sketched out in the previous section. Libertarians such as Simon Young, for example, have tended to dismiss the criticisms of liberals and the Left, arguing that as citizens of poorer nations become more wealthy they will have better access to genetic engineering. ${ }^{51}$ Similarly, Ray Kurzweil notes that as a general rule, the price of new technologies is initially prohibitive for everyone except the wealthiest individuals, but eventually they become more affordable. ${ }^{52}$ 
There is, however, disturbing evidence to the contrary. As Melinda Cooper notes, by the mid-nineties pharmaceutical corporations had developed retroviral therapies which allowed patients in wealthy nations to manage the devastating effects of AIDS, yet millions of HIV-positive individuals in sub-Saharan Africa had no access to the new drugs due to their prohibitive costs. ${ }^{53}$ If that's true in the case of genetic technologies as well, then there are good reasons to approach arguments such as Young's with skepticism (to put it charitably).

Thus, if we're justified in being concerned about the potential implications of genetic enhancement, then what action, political or otherwise, could or should opponents of liberal eugenics take in order to prevent the emergence of a society which is split along increasingly racialized class lines? ${ }^{54}$ One strategy is to simply ban the use of genetic engineering altogether. Yet even the most ardent opponents of human enhancement have recognized the potential value of using genetic engineering for therapeutic purposes. ${ }^{55}$ In any event, there are two serious difficulties with this approach. First, bioethicists have presented wellreasoned arguments in defense of the idea that there is a valid ethical distinction between the use of genetic modifications for purposes of therapy vs. their use for enhancement. ${ }^{56}$ Secondly, and more importantly from a practical vantage point, I believe that the public will view legal prohibitions on technologies which it regards as having the potential to benefit humans as irrational and counterproductive. Thus, a second approach legislators could pursue is to allow genetic engineering for therapeutic purposes but prohibit its use for enhancements. Ultimately, however, it's hard to maintain the distinction, since in both cases one could argue that an agent's capacity is enhanced (if only indirectly in the case of therapeutic interventions). ${ }^{57}$ If the general public also moves in the direction of questioning, and finally rejecting, the proposed distinction, then legislative pressure will eventually undermine the efficacy of the second approach.

A third approach, then, is to allow genetic engineering both for purposes of therapy as well as enhancement, with the government providing regulatory oversight and/or guaranteeing that the poor have access to the requisite technologies. Indeed, various proponents of genetic enhancement have conceded that concerns about worsening social inequality are well-founded, and have speculated about how to distribute access to genetic engineering more fairly, or at least mitigate the impact of its use by elites in society. Maxwell Mehlman, for example, argues that the state could conduct a national 'enhancement lottery', in which every citizen was entered, and individuals would have the right to decline their winnings if they had moral, political or other objections to genetic engineering. ${ }^{58}$ Nicholas Agar defends a Rawslian-style approach in which "[g]oods of genetic engineering must be allocated to an individual in a way that 
improves the prospects associated with all possible life plans-most especially the worst off potential life plan." ${ }^{59}$ James Hughes has argued that the state has an obligation to provide medical care for all its citizens, and that it should offer financial support for enhancements when fiscally possible. ${ }^{60}$ Peter Singer, meanwhile, advances a more radical proposal, suggesting that we could subsidize enhancements for the poor while limiting the access of affluent individuals, ${ }^{61}$ (although he has concerns about this approach, since he believes that a general right to enhancement will ultimately benefit society to the greatest extent possible ${ }^{62}$ ).

While I'd like to reiterate that there are compelling moral and political reasons to oppose the use of genetic engineering for purposes of human enhancement, my analysis in this section has hopefully shown why I'm pessimistic about the chances of enacting effective regulatory controls on its use. If that's the case, and if it's furthermore true that we're concerned about the worsening of social inequality (and at the limit the dissemination of class racism with all of its attendant problems), how should opponents of genetic enhancement conceptualize the future political landscape? Which, if any, of the measures recommended in the preceding paragraph should they embrace? While I realize that the responses I'm about to provide are bound to appear evasive, I nevertheless think that the first question is logically prior to the second, and necessitates caution in giving any answer, however, provisional, to the question of which concrete policy proposals we should endorse.

In thinking about how we should view the political terrain of the future, Foucault's work on biopolitics is indispensable, and this is especially true in the case of the coming battles over the moral legitimacy of genetic engineering. There is nothing particularly surprising or original about this observation. It is, however, important to keep in mind as we approach the inescapable struggles over the future of the species. As Agamben notes, "our private biological body has become indistinguishable from our body politic...But it is by starting from this uncertain terrain that today we must find the path of another politics, of another body, of another word." ${ }^{63} \mathrm{We}$ can either lament this fact and nostalgically pretend that it's possible to restore the public/private distinction, or we can recognize that our bodies, and the body politic more broadly conceived, are sites of political contestation. The mapping of the genome, and its attendant consequences, will only intensify the trajectories which Foucault had already identified in the seventies; the new question we're confronted with, then, is how we can exercise democratic control over the biogenetic technologies which loom on our horizon.

What this entails, more specifically, in the context of the debate surrounding genetic enhancement is that we can't simply defer to the judgments of 'experts' concerning which forms of genetic engineering are/are not appropriate (especially 'experts' who are employed by corporate 
entities which will profit handsomely from the coming genetic revolution); likewise, we can't allow them to dictate which policies to adopt. Indeed, the response from the Right has consisted of an appeal to the moral absolutism of natural law/theology. This strategy is bound to fail, both theoretically (because it presupposes a dubious conception of human nature and fails to recognize the pluralism of modern societies) as well as practically (for the reasons I mentioned above, having to do with the public's general belief that genetic engineering is morally defensible for therapeutic purposes). Rather, it is important to mobilize democratically in order to assert control over the new technologies, with the goal of preventing the kind of two-tiered access I have discussed in previous sections.

In providing this admittedly lengthy answer to the first question I posed, I hope it becomes clear why it's difficult, if not impossible, to answer the second one. If I'm correct that we should struggle to reassert control over our own bodies, and the body politic at a collective level, in a democratic fashion, then we can't give a priori recommendations about which specific policies to adopt. Rather, the primary task of the Left going forward is the collective articulation of how, precisely, we should think, and more importantly respond to, the reshaping of humanity in a progressive fashion. Perhaps we can draw, at least in part, on the work of Hardt and Negri; ${ }^{64}$ however, by seeing the struggle over our biological future as a chance for the multitude of so-called biological 'undesirables' - the weak, the poor, the disabled; in short, all the genetic 'inferiors' who are marginalized by the new biopolitical order-to affirm their power, or as the opening up of new spaces for political contestation which bring contradictions and antagonisms into sharper focus. In this case, as in so many others, the politics of the future will consist of battles which are fought on the terrain of life itself.

${ }^{1}$ Cf. Diane B. Paul, Controlling Human Heredity: 1865 to the Present (Atlantic Highlands, New Jersey: Humanities Press, 1995), 3.

${ }^{2}$ Plato, Republic, 457c-462a.

${ }^{3}$ Quoted in Paul's Controlling Heredity, 3.

4 Readers who would like a general introduction to its historical trajectory should consult Daniel J. Kevles' In the Name of Eugenics (Cambridge: Harvard UP, 1995). For an excellent study of the eugenics movement in the United States, cf. Edward Black's War Against the Weak: Eugenics and America's Campaign to Create a Master Race (New York: Dialog Press, 2008), and for the definitive English-language examination of the role eugenics played in German political discourse in the late eighteenth/early nineteenth centuries, see Paul Weindling's 
Health, Race and German Politics Between National Unification and Nazism, 1870-1945 (Cambridge: Cambridge UP, 1989).

${ }^{5}$ As Claudia Koontz has noted in her masterful study of reproductive politics under the Nazis, entitled Mothers in the Fatherland: Women, the Family and Nazi Politics (New York: St. Martin's Press, 1987) tax policy was used to encourage reproduction (parents with six or more children were exempt from paying personal income tax). Likewise, women who had five or more children were recognized as national heroes; women with five children were given a bronze medal, while six children earned a silver medal; seven, however, was worthy of gold. In addition, antiabortion laws were drafted, since it was important to guarantee the survival of Aryans. Finally, women received state indoctrination in "racial science" classes, including study of the "Ten Commandments for Choosing a Partner." The list contained injunctions such as "[i]f hereditarily fit, do not remain single", "[w]hen choosing your spouse, inquire into his or her forebears" and "[h]ope for as many children as possible" (cited in Koontz, 189).

${ }^{6}$ A good example of this hyper-optimistic evaluation of genetic engineering is Ramez Naam's More than Human (New York: Broadway Books, 2005). Habermas' criticisms are outlined in "The Debate on the Ethical Self-Understanding of the Species" in The Future of Human Nature (Cambridge: Polity Press, 2003).

7 Although Fukuyama's discussion is very brief; it's found on page sixteen of Our Posthuman Future (New York: Farrar, Strauss and Girroux, 2002).

${ }^{8}$ Cf. his “Liberal Eugenics” in Public Affairs Quarterly 12, no. 2 (April 1998): 137.

9 Agar's book was also titled Liberal Eugenics (Malden, Mass.: Blackwell Pub., 2004).

${ }^{10}$ Agar, Liberal Eugenics, 5

11 This is an empirical generalization; I'm not suggesting that there is a necessary connection between levels of economic development and cultural diversity, since there are any number of advanced, postindustrial societies which aren't particularly diverse, such as Japan.

12 Agar, Liberal Eugenics, 121-131.

13 According to Daniel J. Kevles, by the end of the nineteen-twenties twenty-four American states had approved compulsory sterilization practices. In the 1927 case of Buck vs. Bell the U.S. Supreme Court had upheld the constitutionality of a Virginia statue which required the sterilization of "feeble-minded" individuals. Writing for the majority in an eight to one opinion, Justice Oliver Wendall Holmes offered the following comments: "We have seen more than once that the public welfare may call upon the best citizens for their lives. It would be strange it if would not call upon those who already sap the strength of the State for these lesser sacrifices...Three generations of imbeciles are enough." Cf. Kevles, op. cit., 111. For a lengthier account of the Buck vs. Bell case, see Paul A. Lombardo's Three Generations, No Imbeciles: Eugenics, the Supreme Court and Buck vs. Bell (Baltimore: Johns Hopkins UP, 2008).

14 "Our" here refers to the American approach, although the problem I've highlighted would clearly present challenges in any society which has a tiered system, or allows for differential access, based on levels of income.

15 Traverso's account, which is less focused on offering a conceptual demarcation of the term than in providing historical examples of class racism, is found on pages 104-117 of The Origins of Nazi Violence, trans. Janet Lloyd (New York: The New Press, 2003). I'm unable, 
given the limitations of the present essay, to engage in an extended examination of the complex ways in which class and race overlap. The only point I wish to make here is that the phenomena I'm describing as 'class racism' isn't reducible to either traditional classism or modern racism, since it attributes biological characteristics to individuals based on their membership in specific social strata.

${ }^{16}$ Cf. Society Must Be Defended, trans. David Macey (New York: Picador, 2003), 48.

${ }^{17}$ Foucault, Society Must Be Defended, 48.

${ }^{18}$ Foucault, Society Must Be Defended, 49.

${ }^{19}$ Foucault, Society Must Be Defended, 49.

${ }^{20}$ Foucault, Society Must Be Defended, 58.

${ }^{21}$ Foucault, Society Must Be Defended, 59.

${ }^{22}$ Foucault, Society Must Be Defended, 60.

${ }^{23}$ Foucault, Society Must Be Defended, 60.

${ }^{24}$ Foucault, Society Must Be Defended, 60.

${ }^{25}$ Foucault, Society Must Be Defended, 61-62.

${ }^{26}$ Foucault, Society Must Be Defended, 62.

${ }^{27}$ Foucault, Society Must Be Defended, 62.

${ }^{28}$ Cf. Balibar's essay on "Class Racism" in the book he co-authored with Immanel Wallerstein, Race, Nation, Class: Ambiguous Identities (New York: Verso, 1991), 210. For further discussion of the question of "two nations" within a single state see Giorgio Agamben's "What is a People?" in Means without End, trans. Vincenzo Binetti and Cesare Casarino (Minneapolis: University of Minnesota Press, 2000), 31.

${ }^{29}$ Traverso, The Origins of Nazi Violence, 108.

${ }^{30}$ Traverso, The Origins of Nazi Violence, 110.

31 Traverso, The Origins of Nazi Violence, 110. For a fuller discussion of the racialist mileu in nineteenth-century France, see Robert A. Nye's Crime, Madness and Politics in Modern France (Princeton: Princeton UP, 1984), especially 97-170.

32 Cf. "The Birth of Social Medicine" in Power: Essential Works of Michel Foucault, Vol. III, ed. Paul Rabinow (New York: The Free Press, 2000), 152.

33 See the March 17th, 1976 lecture in Society Must Be Defended.

${ }^{34}$ Traverso, The Origins of Nazi Violence, 118-128.

${ }^{35}$ Cf. Black's War Against the Weak, especially 56-61.

36 Cf. Ladelle McWhorter, Racism and Sexual Oppression in Anglo-America: A Genealogy (Bloomington: Indiana UP, 2009), especially 196-244.

37 Joel Garreau actually divides this group into two distinct classes; he designates the Naturals as individuals who have adequate resources but have decided, for moral or political reasons, not to use it, while he designate the group who lack adequate resources but would like to 
use the technologies as 'the Rest'. Presumably 'the Rest' would vastly outnumber either the Naturals or the Enhanced. Cf. Joel Garreau, Radical Evolution: the Promise and Peril of Enhancing Our Minds, Our Bodies-And What it Means to Be Human (New York: Broadway Books, 2005), 157.

Cf. Lee Silver, Remaking Eden: How Genetic Engineering and Cloning Will Transform the American Family (New York: Harper Perennial, 1998), 4-5.

Silver, Remaking Eden, 5.

40 As Fukuyama (rhetorically) asks, "What will happen to political rights once we are able to, in effect, breed some people with saddles on their backs, and others with boots and spurs?" (10).

41 Fukuyama, Our Posthuman Future, 16.

42 Fukuyama, Our Posthuman Future, 9.

${ }^{43}$ Fukuyama, Our Posthuman Future, 157; cf, also Michael Sandel, "The Case Against Perfection: What's Wrong with Designer Children, Bionic Athletes, and Genetic Engineering” in Human Enhancement, eds. Julian Savlescu and Nick Bostrom (Oxford: Oxford UP, 2009), 86-89.

44 Sandel, "The Case Against Perfection," 86.

45 Fukuyama, Our Posthuman Future, 157.

${ }^{46}$ For more on this point see Dan W. Brock's, “Genetic Engineering” in Biomedical Ethics, 6 ${ }^{\text {th }}$ edition, eds. Tomas Mappes and David DeGrazia (New York: McGraw-Hill, 2006), 611.

47 For a lengthier discussion of "genetically at risk" individuals, see Nikolas Rose, The Politics of Life Itself: Biomedicine, Power and Subjectivity in the Twenty-First Century (Princeton: Princeton UP, 2007), 106-130.

48 Rose, The Politics of Life Itself, 116-125.

${ }^{49}$ Rose, The Politics of Life Itself, 119-120.

50 Rose, The Politics of Life Itself, 120.

51 Cf. Julian Young, Designer Evolution: A Transhumanist Manifesto (Amherst, NY: Prometheus Books, 2006), 62-68.

52 Ray Kurzweil, The Singularity is Near (New York: Viking, 2005), 469-70.

53 See Melinda Cooper's Life as Surplus: Biotechnology and Capitalism in the Neoliberal Era (Seattle: University of Washington Press, 2008), 52-53.

54 I think there are compelling moral reasons to oppose genetic enhancement, including the difficulty of assuming the consent of future moral agents whose identities are being fundamentally transformed. In this regard, I find Habermas' arguments in "The Debate on the Ethical Self-Understanding of the Species" compelling. Here, though, I'm more interested in the political dynamics of the situation.

55 Bill McKibben, for example, is one of the fiercest opponents of germline genetic engineering, but he favors the use of somatic gene therapy to minimize the ravaging effects of diseases such as cystic fibrosis. Cf. Enough: Staying Human in an Engineered World (New York: Owl Books, 2003), 9-12. 
${ }^{56}$ A case in point is W. French Anderson, "Human Gene Therapy: Why Draw a Line?," Journal of Medicine and Philosophy 14: 6 (December 1989): 686-687.

${ }^{57}$ For a lengthy, and illuminating, discussion of this question, cf. Allen Buchanan, Dan W. Brock, Norman Daniels and Daniel Wikler, From Chance to Choice: Genetics and Justice (Cambridge: Cambridge UP, 2000), especially 104-155.

${ }^{58}$ Cf. Maxwell Mehlman, The Price of Perfection (Baltimore: John Hopkins UP, 2009), 225-226.

${ }^{59}$ See Agar, "Liberal Eugenics," 150. John Rawls touches on the question, albeit very briefly, in A Theory of Justice (Cambridge: Harvard UP, 1971), 107-108.

60 Hughes' proposal is outlined in Citizen Cyborg: Why Democratic Societies Must Respond to the Redesigned Human of the Future (Cambridge: Westview Press, 2004), 232-239 and 263.

${ }^{61}$ Cf. Peter Singer, "Parental Choice and Human Improvement" in Human Enhancement, eds. Julian Savlescu and Nick Bostrom (Oxford: Oxford UP, 2009), 286.

62 Singer, "Parental Choice and Human Improvement," 286.

63 See Agamben's Means Without Ends: Notes on Politics, trans. Vincento Binetti and Cesare Casarino (Minneaplois: Minnesota UP, 2000), 139.

${ }^{64}$ See their work Empire (Cambridge: Harvard UP, 2000), especially 22-66. 